\title{
Peningkatan Penguasaan Kosakata Anak Tunarungu Melalui Media Gambar Pada Siswa Kelas IV di SLB Negeri Kota Gorontalo
}

\author{
Rita Kadir \\ Guru Kelas IV SLBN Kota Gorontalo \\ rita@gmail.com
}

\begin{abstract}
Received: 04 March 2021; Revised: 26 April 2021; Accepted: 28 July 2021
DOI: http://dx.doi.org/10.37905/aksara.7.3.1185-1192.2021
\end{abstract}

\begin{abstract}
ABSTRAK:
Tujuan Penelitian ini adalah untk mengetahui peningkatan perbendaharaan kata pada mata pelajaran Bahasa Indonesia anak tunarungu pada siswa kelas IV SLB Negeri Kota Gorontalo semester II Tahun Pelajaran 2019/2020, yang diperoleh melalui penggunaan media variasi gambar. Permasalahan yang di kaji dalam penelitian ini adalah 1. Anak Tunarungu SLB Negeri Kota Gorontalo mengalami kesulitan pada pelajaran Bahasa Indonesia dalam hal memahami kata, 2.anak Tunarungu kelas IV SLB Negeri Kota Gorontalo mengalami kesulitan menyusun kalimat dikarenakan miskinnya bahasa, 3. Anak Tunarungu kelas IV SLB Negeri Kota Gorontalo mengalami kesulitan pada pelajaran Bahasa Indonesia dalam hal bicara karena kurangnya Kosa kata yang dikuasainya, 4. Kurangnya media dalam pembelajaran Bahasa Indonesia untuk memperbanyak kosa kata, 5. Belum digunakan media "variasi gambar"dalam upaya meningkatkan perbendaharaan kata.ebut diatas, metode penelitian yang digunakan dalam rangka pengumpulan data menggunakan cara observasi, dokumentasi, dan tes hasil belajar. Tehnik analisis data secara diskriptif yaitu dengan membandingkan nilai antar siklus yang dianalisis adalah tes siswa sebelum menggunakan media variasi gambar dan nilai tes siswa setelah menggunakan media variasi gambar.

Hasil penelitian menunjukan: 1. Melihat hasil kata dari studi awal angka ketuntasan hanya $16,67 \%$ setelah diadakan perbaikan sampai nilai siklus I dan II menunjukan adanya peningkatan yang signifikan dari angka ketuntasan siswa hingga mencapai $100 \%, 2$. Terjadi peningkatan keaktifan siswa dalam proses pembelajaran yang dapat dibaca pada lembar observasi. Dari hasil analisis tersebut dapat disimpulkan bahwa hipotesis yang berbunyi: "Penerapan Media Variasi Gambar dapat meningkatkan kosa kata pada siswa kelas IV SLB Negeri Kota Gorontalo Tahun Pelajaran 2019/2020"Terbukti kebenaranya. Jadi dari penelitian ini dapat disimpulkan bahwa melalui media variasi gambar diharapkan lebih efektif untuk meningkatkan kosa kata dalam Pembelajaran Bahasa Indonesia siswa kelas IV SLB Negeri Kota Gorontalo.
\end{abstract}

Kata Kunci: Kosa kata pada pembelajaran Bahasa Indonesia, Media Gambar, Siswa Tunarungu. 


\section{PENDAHULUAN}

. Komunikasi merupakan kebutuhan mendasar bagi semua orang. Berkomunikasi tentu sangat mudah dilakukan oleh sekelompok orang yang tidak memiliki gangguan. Namun akan menjadi tidak mudah jika komunikasi dilakukan pada orang yang mengalami gangguan komunikasi seperti pada anak tunarungu. Keadaan tersebut akan membuat proses komunikasi berjalan tidak efektif sehingga kebutuhan bersosialisasi menjadi terhambat. Kehilangan kemampuan mendengar pada anak tunarungu baik sebagian atau seluruhnya membawa dampak dalam kehidupan secara komplek (Haenudin, 2013:56). Anak tunarungu akan mengalami hambatan terutama dalam perolehan bahasa dan bicara yang digunakan untuk berkomunikasi dengan orang lain. Hal tersebut berdampak pada sulitnya anak tunarungu dalam pemahaman bacaan materi pelajaran karena miskin bahasa atau kosakata. Tanpa pemahaman yang cukup tentang bahasa, anak akan mengalami kesulitan untuk menangkap konsep pelajaran yang disampaikan oleh guru di kelas.

Dasar dan tujuan pendidikan tuna rungu sama dengan dasar dan tujuan pendidikan bagi siswa normal. Selain tujuan pendidikan umum, pendidikan siswa tunarungu juga mempunyai tujuan pendidikan khusus. Hal ini disebabkan karena siswa Tuna rungu mempunyai karakteristik khusus yang berbeda dengan siswa normal pada umumnya. Tujuan pendidikan khusus untuk siswa tunarungu yaitu; menambah kesadaran siswa dalam mengenal lingkungan alamiah dan lingkungan sosial, mengembangkan kecakapan dasar yang sangat diperlukan untuk berdiri sendiri, memiliki pengetahuan dasar untuk bekal dalam kehidupan sehari-hari. Menurut S.A. Bratanata (2007: 43), tujuan pendidikan khusus bagi siswa tunarungu tentang mengembangkan kecakapan dasar dan memiliki pengetahuan dasar untuk bekal hidup sehari-hari antara lain: a) menanamkan dan memperbesar kepercayaan pada diri sendiri, b) mengembangkan kebiasaan yang baik misalnya pada bidang kesehatan, kebersihan dan keamanan diri, c) mengembangkan kecakapan bahasa, d) mengembangkan kecakapan primer dalam berhitung, e) mengembangkan cara berfikir yang baik, f) melatih siswa dalam menyesuaikan diri dengan lingkungannya, dan mengembangkan bakat-bakat yang ada pada tiap- tiap individu siswa.

Salah satu dari tujuan pendidikan khusus siswa tunagrahita adalah mengembangkan kecakapan bahasa baik bahasa ibu, bahasa nasional maupun bahasa asing. Sesuai dengan dijelaskan bahwa Mata Pelajaran Bahasa Indonesia disajikan kepada siswa SLB agar mereka menyadari dan mengetahui bahwa bahasa Indonesia harus di di terapkan secara baik dan benar seperti yang sudah dikenalnya. Penguasaan bahasa Indonesia bagi siswa SLB Tunarungu merupakan penunjang agar mereka dapat memahami (membaca, berbicara, menulis, mendengarkan) lambang, perintah, larangan atau petunjuk-petunjuk yang sering dijumpai dalam kesehariannya, baik dalam kehidupan bermasyarakat maupun lingkungan pekerjaannya kelak.

Seiring dengan era globalisasi di segala sektor kehidupan, penguasaan bahasa Indonesia merupakan suatu keharusan. Petunjuk-petunjuk di tempat keramaian seperti di kota-kota besar, tempat-tempat pariwisata, tempat perbelanjaan dan fasilitas-fasilitas umum sudah banyak menggunakan petunjuk baik dengan gambar maupun dengan tulisan. Jika siswa SLB tidak dikenalkan atau dibelajarkan tentang bahasa Indonesia yang baik dan benar (baku), maka mereka akan ketinggalan dan akan mengalami kesulitan dalam berkomunikasi kelak. 
Untuk pembelajaran penguasaan kecakapan bahasa berbeda dengan pengembangan kecakapan bahasa ibu maupun bahasa lokal. Bahasa Ibu dan bahasa lokal sedikit banyak siswa tunarungu sudah mengenal dari pergaulan sehari-hari. Tetapi kalau bahasa Indonesia mereka belum maksimal dalam pemahaman dan penggunaanya. Maka dalam pengembangan pembelajaran bahasa Indonesia bagi siswa Tunarungu memerlukan tehnik tersendiri dan media pembelajaran yang menarik agar siswa tunarungu tidak cepat bosan dan perhatiannya terfokus. Tehnik dalam pembelajaran siswa tunarungu harus memperhatikan karakteristik yang ada pada siswa tunarungu. Tehnik pembelajaran pada siswa tunarungu dapat dilakukan sebagai berikut: Perlahan-lahan. Kalau siswa belum memahami bahan yang diajarkan, guru harus bersedia meremidinya sampai siswa memahami betul tentang materi yang di ajarkan. Karena daya tangkap dan konsep siswa berbeda.

Dengan menggunakan media atau contoh yang kongkrit. Hal ini harus dilakukan mengingat daya abstraksi dan daya konsentrasi pada siswa tunarungu. Dengan contoh dan media pembelajaran yang konkrit siswa akan semakin tertarik pada pembelajaran sehingga menimbulkan gairah atau minat untuk belajar. Jika siswa sudah terstimulus minatnya untuk belajar maka siswa akan tahan lama dalam mengikuti pembelajaran. Jika siswa sudah tidak berminat maka pembelajarannya yang diberikan pada siswa kurang bermakna.

Harus banyak menggunakan latihan-latihan. Konsentrasi dan ingatan pada siswa tunarungu sangat bagus maka dalam pembelajarannya perlu mengadakan latihan-latihan sesering mungkin. Baik diadakan di waktu jam sekolah maupun di luar jam sekolah. Banyak menggunakan metode pembelajaran yang mengajak siswa untuk aktif dan mengambil bagian dalam pembelajarannya. Jika siswa dalam proses pembelajarannya tidak aktif maka apa yang diajarkan oleh guru akan sia-sia. Maka usahakan dalam proses pembelajaran siswa dilibatkan secara aktif agar siswa tidak mempunyai kegiatan selain dalam kegiatan belajar itu sendiri. Pengalaman penulis dalam mengajar bahasa Indonesia siswa SLB Tunarungu kelas IV (lebih dari 85\%) mengalami kesulitan dalam penguasaan kosa kata dan mengucapkan lafal kosa kata bahasa Indonesia dengan benar. Hal tersebut mengakibatkan siswa juga mengalami kesulitan dalam belajar komunikasi atau berbicara dalam bahasan Indonesia. Selain itu siswa juga kurang tertarik dalam belajar bahasa Indonesia karena bahasa Indonesia merupakan pelajaran yang sulit untuk dipelajari. Dari permasalahan tersebut mengakibatkan siswa tidak terlibat secara aktif dalam proses pembelajaran. Perhatian siswa tidak fokus dalam proses pembelajaran sehingga hasil belajarnya kurang optimal.

Permasalahan tersebut menurut penulis dikarenakan karakter negatif yang ada pada siswa tunarungu. Mengingat karakteristik siswa tunarungu tersebut maka diperlukan media pembelajaran yang mampu mengajak siswa untuk aktif dalam pembelajaran dan dapat dilakukan secara berulang-ulang oleh siswa baik dalam jam pelajaran di sekolah maupun di luar jam pelajaran sekolah. Berkaitan dengan permasalahan yang dialami oleh siswa SDLB tunarungu kelas IV di SLB Negeri Kota Gorontalo dalam belajar penguasaan kosa kata bahasa Indonesia tersebut maka penulis mencoba memberikan pemecahan masalah dengan pembuatan media pembelajaran Variasi Gambar yang berisi gambar dan kosa-kata bahasa Indonesia sebagai suatu cara untuk meningkatkan kemampuan penguasaan kosa-kata bahasa Indonesia secara aktif dan tidak terbalik-balik. 
Tujuan yang ingin dicapai dalam penelitian tindakan kelas ini adalah sebagai berikut: Untuk meningkatkan kosa kata Bahasa Indonesia siswa kelas IV di SLB Negeri Kota Gorontalo Pada Tahun Pelajaran 2019/2020 melalui Media Variasi Gambar.

Hasil dari penelitian ini diharapkan dapat Meningkatkan keaktifan siswa dalam proses pembelajaran. Meningkatkan kemampuan penguasaan kata bahasa Indonesia pada siswa tunarungu.

Hipotesis yang diajukan peneliti Penggunaan Media Variasi Gambar penguasaan kosa kata anak Tunarungu kelas IV SDLB di SLB Negeri Kota Gorontalo Tahun Pelajaran 2019/2020 dapat meningkat.

\section{METODE PENELITIAN}

Penelitian Tindakan Kelas (PTK) dalam bahasa Inggris diartikan Classroom Action Research (CAR) yaitu penelitian yang dilakukan oleh guru kelas atau di sekolah tempat mengaja, dengan penekanan pada penyempurnaan atau peningkatan praktik dan proses dalam pembelajaran (Susilo, 2007:16).

Penelitian tindakan kelas ini, penulis. lakukan pada semester genap tahun pelajaran 2019/2020 siswa SDLB Tuna Rungu di SLB Negeri Kota Gorontalo kelas IV yang berjumlah 3 peserta didik yang terdiri dari 4 laki-laki dan 2 perempuan. Ke enam peserta didik ini termasuk kategori tuna rungu. Penulis melakukan penelitian ini selama 4 bulan, yaitu Januari, Februari, Maret dan Apri 2020.

Tehnik pengumpulan data dalam penelitian tindakan kelas tidak hanya menggunakan satu tehnik tetapi menggunakan multi tehnik pengumpulan data. Menurut Wolcot dalam Nana Syaodih Sukmadinata (2005:151) ada tiga kelompok tehnik pengumpulan data yaitu; pengalaman, pengungkapan dan pengujian. Adapun data dalam penelitian tindakan kelas ini, yang dibutuhkan adalah data penelitian tentang: Partisipasi Siswa/ observasiUntuk mendapatkan data tentang keaktifan siswa dalam mengikuti proses pembelajaran dibutuhkan lembar pengamatan. Lembar pengamatan ini digunakan pada saat proses pembelajaran dari siklus ke-1 sampai dengan siklus ke-2. Langkah ini biasa disebut dengan istilah pengamatan partisipatif. Kemampuan melafalkan kosa kata bahasa Indonesia. Data kemampuan melafalkan kosa kata bahasa Indonesia dengan benar didapatkan dari proses pengamatan yang dilakukan oleh guru pada saat proses pembelajaran dengan menggunakan kartu gambar berantai dibantu dengan menggunakan alat lembar pengamatan. Langkah ini biasa disebut dengan istilah pengamatan partisipatif.

Kemampuan penguasaan kosa kata bahasa Indonesia. Untuk memperoleh data dengan melakukan: Test. Data kemampuan penguasaan kosa kata bahasa Indonesia ini didapatkan melalui pre test dan post yang dilakukan pada peserta didik. Pretest dilakukan pada saat awal sebelum siklus ke-1 dilakukan. Pre test dilakukan untuk mengetahui dan meyakinkan bahwa penguasaan kosa kata bahasa Indonesia peserta didik masih kurang. Sedangkan post test dilakukan setelah siklus ke-1, dan ke-2 dilakukan. Hal ini dilakukan untuk mengetahui perkembangan penguasaan kosa kata bahas Indonesia pada peserta didik. Kegiatan ini juga disebut pengukuran hasil belajar.

Wawancara sebagai sarana penggalian data Belajar mandiri penguasaan kosa kata bahas Indonesia dengan menggunakan kartu gambar berantai. Data tentang belajar mandiri penguasaan kosa kata bahasa Indonesia dengan menggunakan media kartu gambar berantai ini didapat dari hasil wawancara yang dilakukan kepada orang tua siswa. 
Dalam wawancara ini dibantu dengan alat atau naskah wawancara yang ditujukan kepada orang tua.

Data yang digunakan dalam penelitian tindakan kelas ini adalah data kuantitatif dan data kualitatif. Data kuantitatif berupa data angka yang diperoleh dari pre test dan post test. Analisis data kuantitatif ini menggunakan analisis deskriptif dan sajian visual berupa tabel dan grafik. Sajian data berupa tabel dan grafik ini menggambarkan bahwa tindakan yang dilakukan dapat menimbulkan adanya perbaikan, peningkatan atau perubahan ke arah yang lebih baik.

Sedangkan data kualitatif analisis yang dilakukan juga secara kualitatif. Proses analisis kualitatif ini menurut Sudarsono (2001:26), melalui tahap yaitu; menyeleksi, menyederhanakan, mengklasifikasikan, memfokuskan, mengorganisasikan secara sistematis dan logis serta membuat abstraksi atas kesimpulan makna hasil analisis. Data kualitatif ini adalah data dari hasil wawancara kepada peserta didik dan orang tua.

\section{PEMBAHASAN}

Data hasil prestasi belajar siswa kelas IV yang diperoleh dari pelajaran Bahasa Indonesia disajikan dalam tabel. Agar dalam pelaksanaan peneliti tidak mengalami kegagalan, maka penulis merencanakan penelitian tindakan kelas ini dalam 2 siklus, dengan media yang sama. Pelaksanaan 2 siklus dalam penelitian tindakan kelas tersebut penulis uraikan sebagai berikut: Siklus ke-1 (pertama), penulis mengajarkan tentang pengenalan kosa kata melalui media kartu gambar berantai. Penulis menjelaskan cara menggunakan kartu gambar. Setelah itu, peserta didik dibagi menjadi 2 kelompok. Setiap kelompok berjumlah 3 peserta didik. Pada tahap pertama ini peserta didik masih mengalami kesulitan untuk memainkan kartu gambar berantai. Kelemahan yang terjadi pada siklus pertama peserta didik masih belum mengetahui cara bermain serta menyebutkan atau melafalkan kosa kata belum benar. Kelemahan yang terjadi pada siklus 1 penulis catat dalam suatu catatan tersendiri. Kemudian dibuat strategi perbaikan untuk memperbaiki siklus berikutnya.

Hasil penelitian ini diuraikan berdasarkan fenomena yang terjadi setiap siklus. Data yang penulis laporkan diambil dari 2 sumber yaitu: Hasil penguasaan kosa kata bahasa Indonesia melalui post test setelah setiap siklus selesai dilaksanakan peserta didikan. Pengamatan di kelas melalui lembar observasi atau lembar pengamatan dilakukan pada setiap siklus.

Hasil wawancara dengan subyek penelitian dan orang tua subyek penelitian. Adapun hasil penelitian di uraikan dalam tahapan siklus sebagai berikut: Pada siklus I, setelah diadakan penjelasan terhadap penggunaan Kartu Gambar Berantai, siswa dibagi menjadi 2 kelompok. Setiap kelompok berjumlah 3 siswa. Pada saat bermain siswa terlihat masih belum lancar memainkan kartu variasi gambar sehingga mengakibatkan siswa kurang aktif. Demikian pula pada pelafalan kosa-kata siswa masih mengalami kesulitan. Sebagai contoh melafalkan kata mother, seharusnya huruf „o" pada kata mother di baca „a"tetapi mereka membaca seperti apadanya „o" di baca „o". Pada akhir pembelajaran dengan menggunakan permainan kartu gambar berantai setelah pertemuan ke 2, diadakan post test untuk mengetahui kemampuan penguasaan kata yang dikuasainya.

Terdapat 3 siswa (50\%) yang aktif dalam proses pembelajaran dengan menggunakan kartu gambar berantai. Ketiga siswa ini selain bermain dengan baik, juga 
membantu temannya yang mengalami kesulitan, atau bahkan mendorong temannya untuk memperhatikan cara bermainnya.

Terdapat 2 siswa $(33,33 \%)$ yang sudah cukup baik melafalkan kosa kata bahasa Indonesia pada saat proses pembelajaran. Terdapat 2 siswa $(33,33 \%)$ yang mencapai nilai lebih dari $75 \%$ dalam penguasaan kosa kata yang harus dikuasainya.

Pada siklus II, setelah diadakan perbaikan terhadap penggunaan Kartu Gambar Berantai pada siklus I, siswa dibagi menjadi 2 kelompok. Setiap kelompok berjumlah 3 siswa. Setiap kelompok selain mendapatkan Kartu Gambar Berantai juga mendapatkan kamus gambar tentang tema dan materi yang terdapat pada pada Kartu Gambar Berantai. Pada saat bermain siswa terlihat ada kemajuan dalam memainkan kartu gambar berantai. Pelafalan pengucapan kosa-kata bahasa Inggris yang sesuai dengan gambar, terlihat mengalami peningkatan. Pengucapan atau pelafalan kata mother, sudah benar. Tidak terdengar lagi huruf „o" pada kata mother di baca ,a". Setelah 2 kali pertemuan pada siklus ke-II diadakan post test untuk mengetahui kemampuan penguasaan kata yang dikuasainya.

Pada siklus ke II ini siswa terlihat sudah lancar memainkan kartu gambar berantai, sehingga seluruh siswa sudah terlihat aktif dalam proses pembelajaran dengan kartu gambar berantai. Demikian pula pelafalan atau pengucapan kosa-kata yang sesuai dengan gambar terlihat mengalami peningkatan walaupun terlihat siswa sangat hati-hati sebelum mengucapkan kosa-kata yang dimaksud. Adapun data hasil pengamatan dan post test adalah sebagai berikut: Terdapat 6 siswa (100\%) aktif dalam proses pembelajaran dengan meng gunakan kartu gambar berantai. Terdapat 5 siswa $(83,33 \%)$ yang sudah baik dan benar dalam melafalkan kosa kata bahasa Indonesia pada saat proses pembelajaran. Terdapat 5 siswa $(83,33 \%)$ yang mencapai nilai lebih dari $75 \%$ dalam penguasaan kosa kata yang harus dikuasainya.

Dari tabel dan grafik diatas,dapat dilihat perkembangan siswa selama dua siklus. Pada Pra Siklus siswa yang aktif dalam proses pembelajaran hanya 50\% kemudian meningkat pada siklus ke-1 menjadi 83,33\% dan siklus ke-2 menjadi 100\%. Untuk kemampuan melafalkan kosa kata bahasa Indonesia dengan benar adalah sebagai berikut; siklus ke-1 hanya 33,33\% siswa yang mampu melafalkan kosa kata bahasa Indonesia dengan benar. Kemudian pada siklus ke-1 meningkat menjadi 50\% dan pada siklus ke-2 meningkat menjadi $83,33 \%$. Sedangkan untuk perkembangan kemampuan penguasaan kosa kata bahasa Indonesia penulis jelaskan sebagai berikut; siswa yang mampu meningkatkan siswa yang mampu meningkatkan penguasaan kosa kata bahasa Indonesia dari target yang diharapkan pada siklus ke-1 memperoleh $66,67 \%$ dan pada siklus ke-2 menjadi $83,33 \%$.

\section{PENUTUP}

Hasil penelitian tindakan kelas di atas maka dapat ditarik kesimpulan bahwa indikator yang ditargetkan oleh penulis dengan menggunakan media kartu gambar berantai adalah sebagai berikut: Hal dapat dilihat perkembangan siswa selama dua siklus. Untuk kemampuan melafalkan kosa kata bahasa Indonesia dengan benar adalah sebagai berikut; siklus ke-1 hanya 33,33\% siswa yang mampu melafalkan kosa kata bahasa Indonesia dengan benar. Kemudian pada siklus ke-1 meningkat menjadi 50\% dan pada siklus ke-2 meningkat menjadi 83,33\%. Sedangkan untuk perkembangan kemampuan penguasaan kosa kata bahasa Indonesia penulis jelaskan sebagai berikut; 
siswa yang mampu meningkatkan penguasaan kosa kata bahasa Indonesia dari target yang diharapkan pada siklus ke-1 memperoleh $66,67 \%$ dan pada siklus ke-2 menjadi $83,33 \%$. Dari data yang di diperoleh menunjukan peningkatan yang signifikan.

Bertolak dari kesimpulan hasil penelitian di atas, maka penulis mengajukan saran sebagai berikut: Saran untuk Pendidik: Berdasar hasil penelitian di atas, bahwa media pembelajaran mempunyai peran yang besar dalam mengefektifkan proses pembelajaran maka seharusnya para pendidik berusaha untuk mencari atau membuat media pembelajaran yang cocok dengan tema atau materi yang di ajarkan dalam proses pembelajaran. Apalagi peserta didik adalah anak berkebutuhan khusus yang mempunyai banyak kekurangan.

Saran untuk Peneliti: Penelitian tentang media Variasi Gambar ini dapat dikembangkan pada tema atau materi yang lain selain tema keluarga dan profesi manusia serta nama-nama binatang yang sudah diteliti dalam penelitian ini. Penelitian tentang media Kartu Gambar Berantai ini dapat dikembangkan kepada peserta didik yang mempunyai kelainan atau kebutuhan khusus yang lain selain peserta didik tunarungu.

\section{DAFTAR PUSTAKA}

Agus Suprijono. 2010. Cooperative Learning Teori dan Aplikasi PAIKEM. Yogyakarta: Pustaka Pelajar.

Arief S. Sadiman, dkk. 2009. Media Pendidikan. Jakarta: Raja Grafindo Persada.

Aristo Rahadi. 2003. Media Pembelajaran. Jakarta: Depdiknas, Dirjen Dikdasmen.

Geniofam. 2010. Mengasuh dan Mensukses- kan Anak Berkebutuhan Khusus. Yogyakarta: Gerailmu.

Ibrahim Bafadal. 2003. Peningkatan Profesionalisme Guru, Jakarta: Bumi Aksara.

Iskandar. 2009. Psikologi Pendidikan (Sebuah Orientasi Baru). Jakarta: Gaung Persada Press.

Margono. 2009. Metode Penelitian Pendidikan.

Jakarta: Rineka Cipta.

Mohammad Efendi. 2006. Pengantar Psikopedagogik Anak Berkelainan. Jakarta: Bumi Aksara.

Muhammad Ali. 2006. Guru dalam Proses Belajar Mengajar. Bandung: Sinar Baru Algesindo.

Mulyono Abdurrahman. 2003. Pendidikan Bagi Anak Berkesulitan Belajar. Jakarta: Depdikbud dan Rineka Cipta.

Lani Bunawan dan Cicilia Susila Yuwati. 2000. Penguasaan Bahasa AnakTunarungu. Jakarta. Yayasan Santri Rama.

Muhamad Efendi. 2006. Pengantar Psikopedagogik Anak Berkelainan, Jakarta. Bumi Aksara.

Muh Bandi. 1997. Psykologi Anak Luar Biasa/ Berkelainan. Kota Gorontalo. UNS.

Munzayanah. 2000. Pendidikan Nana Sudjana dan Ahmad Rivai, 2000. Media Pengajaran. Bandung: Sinar Baru Algensindo..

Rusli Ibrahim. 2005. Psikologi Pendidikan Jasmani Olah Raga PLB, Jakarta: Depdiknas. Suharsimi Arikunto. 2006. Prosedur Penelitian Suatu Praktek. Jakarta: Rineka Cipta. Umaedi. 1999. Manajemen Peningkatan Mutu Berbasis Sekolah. Jakarta: Depdiknas. Undang-Undang No. 20 Tahun 2003. Sistem Pendidikan Nasional (SISDIKNAS). Bandung: Citra Umbara. 
AKSARA: Jurnal Ilmu Pendidikan Nonformal

P-ISSN 2407-8018 E-ISSN 2721-7310 DOI prefix $\underline{10.37905}$

Volume 07, (03) September 2021

http://ejurnal.pps.ung.ac.id/index.php/Aksara 